\title{
IAMJ
}

INTERNATIONAL

AYURVEDIC

MEDICAL JOURNAL

\section{EVALUATION OF PHYSICOCHEMICAL AND PHYTOCHEMICAL COMPOSITION OF DRY SHIGRU PATRA (MORINGA OLEIFERA LAM. LEAF) OF ISLAND (PORT BLAIR) AND MAINLAND (CHHATTISGARH)}

\author{
Paramjeet Kaur Sethi ${ }^{1}$, Pravin Kumar Joshi ${ }^{2}$, Rakshapal Gupta ${ }^{3}$ \\ ${ }^{1}$ MD Scholar, Department of Dravyaguna Vigyan, Shri NPA Govt Ayurvedic college, Raipur, Chhattisgarh, India \\ ${ }^{2}$ HOD \& Professor, Department of Dravyaguna Vigyan, Shri NPA Govt Ayurvedic college, Raipur, Chhattisgarh, \\ India \\ ${ }^{3}$ Principal, Govt Ayurveda college, Bilaspur, Chhattisgarh, India
}

Corresponding Author: kaurparamjeet90@gmail.com

https://doi.org/10.46607/iamj06p5022020

(Published online: January 2021)

Open Access

(C) International Ayurvedic Medical Journal, India 2020

Article Received: 13/01/2021 - Peer Reviewed: 24/01/2021 - Accepted for Publication: 02/02/2021

Check for updates

\begin{abstract}
Moringa oleifera Lam is from the family Moringaceae and it is the only genus in this family. It is known as Shigru, Sehjan, Shobhanjan, Teekshngandha, Aksheev in ayurvedic literature. Ancient times have given importance for Desha (habitat) in which the plant is grown and collected. Quality of a Dravya depends on its place of origin (Desha) and Bhumi (soil) and many more factors like climate, water, rainfall, temperature. In Ayurveda there are 3 types of Desha mentioned Jaangal, Sadharan, Anoop Desha. In this research we consider two different places Island (Port Blair) and Mainland (Chhattisgarh). The present study aims at collecting sample from two different geographical regions and comparing their detailed physicochemical and phytochemical composition. Different extracts were prepared using the soxhlation method and these were used for physicochemical and phytochemical analysis. The findings of the study can be progressive for further research. This study suggests that environmental conditions result in very little differences in Physicochemical and Phytochemicals.
\end{abstract}

Keywords: Moringa oleifera Lam, shigru, Desha 


\section{INTRODUCTION}

Moringa oleifera Lam of the family Moringaceae popularly called miracle tree is a native of subHimalayan tracts of northern India and is widely cultivated in tropical and subtropical regions. The plant is bitter, anti-bacterial ${ }^{1}$, antifungal ${ }^{2}$, anti gastric ${ }^{3}$, analge$\mathrm{sic}^{4}$, anti inflamatory ${ }^{5}$, cardio protective ${ }^{6}$, wound healing $^{7}$ etc. Research on Moringa oleifera Lam mainly pivoted around its leaves and seeds because of their immense nutraceutical properties. Moringa is the sole genus in the family Moringaceae. It is a multipurpose plant that is being promoted as a sustainable source of bioactive phytochemicals and nutrients to reduce human and animal malnutrition. It is one of the richest plant sources of Vitamin A, B, C, D, E and K (Anwar and bhanger,2003;babu 200 ); (acres et al;1992;dayrit et al,1990;delisle et al,1997). It has potential benefit in malnutrition, general weakness, lactating mothers, menopause, depression and osteoporosis. It is also used to make efficient fuel, livestock feed and fertilizer (Mcburny et al 2004; Fahey,2005; Danmalam et al;2001). Taxonomical classification: KingdomPlantae, Sub kingdom- Tracheobionta, Superdivision- Spermatophyta, Division- Magnoliophyta, Class- Magniliopsida, Subclass- Dilleniidae, OrderCapparells, Family- Moringaceae, Genus- Moringa, Species- Oleifera. In Ayurveda there are 3 Desha as mentioned by Acharya Charaka, Sadharan Desha, Jaangal Desha, Anoop Desha. Drugs possess properties according to their origin. By doing this research we will be able to detect the differences in Physicochemical and Phytochemicals of Moringa oleifera Lam. leaves due to different geographical regions.

\section{Materials and Methods}

Collection of the Drug: The drug for the present study has been collected from its reported habitat and place i.e. Island (Port Blair) and Mainland (Raipur, Chhattisgarh).

Authentication of The Drug Authentication is done in the Raw Material Herbarium \& Museum, Delhi (RHMD), National Institute of Science Communication and Information Resources (CSIR-NISCAIR) Dr. K.S. Krishna Marg, New Delhi.
Sample 1- Moringa oleifera Lam. (Port Blair) Ref no.-NISCAIR/RHMD/Consult/2018/3286-87-1

Sample 2- Moringa oleifera Lam. (Raipur) -Ref NO.NISCAIR/RHMD/Consult/2018/3286-87-2

\section{Determination of Physicochemical Parameters}

Foreign matter-The entire contents are spread in a thin layer in a suitable dish or tray. Examine in day light with unaided eye. Suspected particles, if any, it is transferred to a petri dish and examined with 10x lens in daylight.

Determination of LOD (Loss on drying)-About $5 \mathrm{gm}$ powdered drug is kept in hot air oven at $105^{\circ} \mathrm{C}$ in for 1 hour. After cooling in desiccators, the loss in weight was recorded. The procedure is repeated till constant weight is obtained.

\section{Determination of Ash Value}

Determination of Total Ash Value-About Two to three $g$ of weighed sample is incinerated in a tarred platinum or silica dish at a temperature not exceeding $450^{\circ} \mathrm{C}$ until free from carbon, cooled and weighed.

Determination of Acid Insoluble Ash-To the crucible containing total ash, $25 \mathrm{ml}$ of dilute hydrochloric acid, the insoluble matter is collected on an ash less filter paper (Whatman 41) and washed with hot water until the filtrate is neutral. The filter paper containing the insoluble matter is transferred to the original crucible, dried on a hot plate and ignited to constant weight. The residue is cooled in a suitable desiccator for 30 minutes and weighed without delay. The content of Acid insoluble ash is calculated with reference to the air-dried drug.

\section{Determination of Extractive Value}

Determination of Alcohol Soluble Extractive (ASE) Value-5 $\mathrm{g}$ of the air dried drug is macerated, coarsely powdered, with $100 \mathrm{ml}$ of alcohol the specified strength in a closed flask for 24 hours, shaken frequently during 6 hours and allow to stand for 18 hours. $25 \mathrm{ml}$ of the filtrate is evaporated to dryness in a tarred flat-bottomed shallow dish, dried at $105^{\circ} \mathrm{C}$, to constant weight and weighed. Percentage of alcohol soluble extract is calculated with reference to the airdried drug. 
Determination of Water Soluble Extractive (WSE) Value-5 $\mathrm{g}$ of the air dried drug is macerated, coarsely powdered, with $100 \mathrm{ml}$ of chloroform water the specified strength in a closed flask for twenty four hours, shaken frequently during six hours and allow to stand for eighteen hours. Filtered taking precautions against loss of solvent, $25 \mathrm{ml}$ of the filtrate is evaporated to dryness in a tarred flat-bottomed shallow dish, dried at $105^{\circ} \mathrm{C}$, to constant weight and weighed. Percentage of water-soluble extract is calculated with reference to the air-dried drug.

pH value -An accurately weighed 10 grams of drug was dissolved in accurately measured $100 \mathrm{ml}$ of water and filtered and the $\mathrm{pH}$ of filtrate was checked with a standardized glass electrode.

\section{Phytochemical Analysis}

Extraction of plant material-The 100-gram powdered drug was placed into Soxhlet apparatus and extraction was carried out using solvent (Alcohol 90\% and distilled water).

\section{Preliminary Phytochemical Screening}

Test for Carbohydrate: Molisch's test -The test solution is combined with a small amount of Molisch's reagent in a test tube. Concentrated Sulfuric acid is slowly added without mixing, to form a layer. A positive reaction is indicated by appearance of a purple red ring at the interface between the acid and test layers.

Test for Reducing sugars: Benedicts test- $5 \mathrm{ml}$ of Benedict's reagent is pipetted in a test tube (20 $\mathrm{x} 150 \mathrm{~mm}) .8$ drops of sample is added to the Benedict's reagent. Carefully heated for 5-10 minutes. Cool under tap water. Reddish precipitate is formed within three minutes indicate reducing sugars.

Test for Monosaccharides: Barfoed's test- Barfoed's reagent. $1 \mathrm{ml}$ of test sample is taken in dry test tube $1 \mathrm{ml}$ of distilled water is taken in another tube as control. Add 2ml of Barfoed's reagent to all the tubes kept in boiling water bath. Development of brick red color ppt. within 3 to 5 minutes indicates the presence of monosaccharide.

Test for Pentose sugar: Bial's Orcinol test $-2 \mathrm{ml}$ of Bial's reagent is taken in test tube. 4-5 drops of test solution are added to this reagent, kept in water bath for 30 seconds. Positive test: Formation of blue color indicates pentose sugar.

Test for Hexose Sugar: Selwinoff's test $-1 \mathrm{ml}$ of sample is taken in test tube and $1 \mathrm{ml}$ of distilled water is taken in another tube as control. $3 \mathrm{ml}$ of Selwinoff's reagent in both test tubes, kept in water bath for 12 minutes. Positive Selwinoff's test; fructose and sugar Test for Proteins: Millon's test- $1 \mathrm{ml}$ test solution is taken in dry test tube. Similarly, $1 \mathrm{ml}$ of distilled water is taken in another test tube as control.1 $\mathrm{ml}$ of Millon's reagent is added and mixed well. Boil gently for 1 minute.Cooled under tap water. Then add 5 drop of $1 \%$ sodium nitrite. Heat the solution slightly. Positive Millon's test; brick red color (tyrosine and phenol solution)

Test for amino acid: Tyrosine test- $1 \mathrm{ml}$ of test solution is taken in dry test tube. Similarly, $1 \mathrm{ml}$ of distilled water is taken in another test tube as control. $1 \mathrm{ml}$ of conc. HNO3 is added in all test tubes and mix well. The solution is cooled under tap water. Then $2 \mathrm{ml}$ of $40 \% \mathrm{Na} \mathrm{OH}$ is added to all the test tubes.

Positive Xanthoproteic test: color changes from yellow to orange.

Test for non-reducing sugar: Iodine test-when iodine solution which is red added to starch, it turns blue/black.

Test for steroid: Salkowski reaction testChloroform solution of the extract when shaken with concentrated sulfuric acid and on standing yields red color.

Test for Flavonoids: Sulfuric acid test $-5 \mathrm{ml}$ of dilute ammonia solution were added to a portion of the aqueous filtrate of each sample extract followed by the addition of concentrated $\mathrm{H}_{2} \mathrm{SO}_{4}$.A yellow coloration observed in each extract indicates the presence of flavonoids.

Test for alkaloids: Tannic acid test-Test solution treated with $10 \%$ tannic acid solution gives yellow (buff) colored precipitate.

Test for tannins: Lead acetate solution test-test using distilled water and $3 \mathrm{ml}$ of $10 \%$ lead acetate solution. A bulky white precipitate indicates the presence of phenolic compounds. 
Test for cardiac glycosides: Keller-Killiani test-To $2 \mathrm{ml}$ of extracts, add glacial acetic acids, one drop of $5 \%$ ferric chloride solution and $2 \mathrm{ml}$ concentrated sulfuric acid was added. Presence of cardiac glycosides is indicated by formation of reddish-brown color at the junction of the two liquid layers and upper layer appeared bluish green darkening with standing.

Test for anthraquinone glycosides: Borntrager's test-The drug is boiled with dilute sulfuric acid, filtered and to the filtrate benzene, or ether or chloroform is added and shaken well. The organic layer is separated to which ammonia is added slowly. The ammoniacal layer shows pink to red color due to the presence of anthraquinone glycosides.

Test for coumarin glycosides: $\mathrm{Na} \mathbf{O H}$ test- $1 \mathrm{ml}$ of the plant extract was taken in a small test tube and covered with filter paper moistened with $1 \mathrm{~N} \mathrm{NaOH}$. The test tube was placed for few minutes in boiling water. Then the filter paper was removed and examined in UV light for yellow fluorescence to indicate the presence of coumarins.

Test for saponin glycosides: Foam test- $1 \mathrm{ml}$ solution of extract was diluted with distilled water to $20 \mathrm{ml}$ and shaken in a graduated cylinder for 15 minutes. Development of stable foam suggests the presence of saponins.

Estimation of Total Flavonoid Compound-Total flavonoid content of the sample was determined by aluminium chloride colorimetric method, quercetin was used as standard concentration.

Estimation of Total Phenolic Compound-Total phenols content of sample was determined by with the Folin-Ciocalteu colorimetric method, Gallic acid was used as standard.

Thin Layer Chromatography (TLC) ${ }^{7}$

Extract: Alcoholic extract of drug sample; Solvent system (Mobile phase):

Toulene: Ethyl acetate $(9: 1 \mathrm{v} / \mathrm{v})$; Method: The tank was prepared by lining the wall with sheets of filter paper, sufficient amount of mobile phase was poured into the tank to form a layer of solvent 5 to $10 \mathrm{~mm}$ deep, the tank was closed and allowed to stand for 1 hour at room temperature. From the vertical sides of the plate, a narrow strip of the coating substance about $5 \mathrm{~mm}$ wide was removed. The solution being examined was applied in the form of circular spots about 2 to $6 \mathrm{~mm}$ in diameter on a line parallel with, and $20 \mathrm{~mm}$ from, one end of the plate was marked $15 \mathrm{~cm}$ from the starting line. The solvent was allowed to evaporate, and the plate was placed in the tank, ensuring that it was as nearly vertical as possible and that the spots were above the level of the mobile phase. The tank was closed and allowed to stand at room temperature, until the mobile phase has ascended to the marked line. The plate was removed and dried and visualized as directed in the monograph.; Visualization: Examined under UV light (254 $\mathrm{nm}$ and $365 \mathrm{~nm}$ ).;

$\mathbf{R}_{\mathbf{f}}$ value: the $\mathrm{R}_{\mathrm{f}}$ (retardation factor) value was calculated by dividing the distance travelled by the spot by distance travelled by the spot of the mobile phase.

\section{Qualitative Analysis for Inorganic Elements-}

Test for magnesium-Gives white ppt. with ammonium carbonate solution but not with ammonium chloride solution.

Test for potassium-To 2-3 ml test solution, add few drops sodium cobalt nitrite solution. Yellow ppt. of potassium cobalt nitrite is observed.

Test for iron-To $5 \mathrm{ml}$ test solution few drops of $2 \%$ potassium ferro cyanide is added. Dark blue color is observed.

Test for sulphates-When lead acetate is added, reagent gives white ppt. soluble in a $\mathrm{NaOH}$.

Test for phosphate-To $5 \mathrm{ml}$ of test solution prepared in HNO3, few drops of ammonium molybdate solution is added. Heated for 10 minutes cooled. Yellow crystalline ppt. of ammonium phosphomolybdate is observed.

Test for chloride-To about 5 to $7 \mathrm{ml}$ filtrate, 3 to $5 \mathrm{ml}$ of lead acetate solution is added. White precipitate soluble in hot water is observed.

Test for carbonates-With solution of magnesium sulphate, white ppt.is observed.

Test for sodium-10ml ash extract and $2 \mathrm{ml}$ of potassium pyroanthllollate gives white precipitate.

Test for nitrates-Liberates red fumes when warmed with sulphuric acid and water. 


\section{Results}

Physicochemical analysis

Table 1: Determination of Physicochemical parameters of Shigru Patra

\begin{tabular}{|l|l|l|l|}
\hline S.No. & Physicochemical parameters & Sample 1 & Sample 2 \\
\hline 1 & Foreign matter & $0.196 \%$ & $1.75 \%$ \\
\hline 2 & total ash & $11.358 \%$ & $11.376 \%$ \\
\hline 3 & Acid insoluble ash & $1.086 \%$ & $1.673 \%$ \\
\hline 4 & Water soluble extractive & $42.412 \%$ & $41.988 \%$ \\
\hline 5 & Alcohol soluble extractive & $6.188 \%$ & $8.648 \%$ \\
\hline 6 & Loss on drying & $14.794 \%$ & $11.829 \%$ \\
\hline 7 & pH (10\% solution) & 6.35 & 6.28 \\
\hline
\end{tabular}

\section{Phytochemical Analysis}

\section{Preliminary phytochemical screening}

Table 2: Preliminary phytochemical analysis of Alcoholic extract of Shigru Patra

\begin{tabular}{|l|l|l|}
\hline Phytochemical analysis & Sample 1 & Sample 2 \\
\hline Carbohydrates & + & + \\
\hline Reducing sugars & + & + \\
\hline Monosaccharides & - & - \\
\hline Pentose sugar & - & - \\
\hline Hexose sugar & - & + \\
\hline Protein & + & + \\
\hline Amino acid & - & - \\
\hline Non reducing sugar & - & - \\
\hline Steroids & + & + \\
\hline Flavonoids & + & + \\
\hline Alkaloids & + & + \\
\hline Tannins & + & - \\
\hline Cardiac glycosides & - & - \\
\hline Anthraquione & - & - \\
\hline Coumarine glycosides & - & + \\
\hline Saponin glycosides & & \\
\hline
\end{tabular}

Table 3: Preliminary phytochemical analysis of Aqueous extract of Shigru Patra

Types of extract

Water

Alcohol
Results sample 1

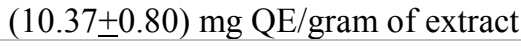

$(72.09 \pm 1.14) \mathrm{mg} Q \mathrm{QE} / \mathrm{gram}$ of extract
Results sample 2

-BDL-

(35.24 \pm 0.22$) \mathrm{mg} Q \mathrm{QE} /$ gram of extract

Table 4: Estimation of Total Flavonoid compound

Phytochemical analysis

Carbohydrates

Reducing sugars

Mono sacchaarides

Pentose sugar

Hexose sugar

Proteins

Amino acid

Non reducing sugars

Steroid

Flavonoids

Alkaloids

\section{Sample 1}

+
+
+
-
+
+
+
+
+

Sample 2

$+$

$+$

$+$

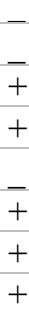




\begin{tabular}{|c|c|c|}
\hline Tannins & + & + \\
\hline Cardiac glycosides & _- & + \\
\hline Anthraquinone & _ & - \\
\hline Coumarine glycosides & & \\
\hline Saponin glycosides & + & + \\
\hline
\end{tabular}

Data are mean \pm SEM for triplicate measurements

Table 5: Estimation of Total Phenolic compound

\begin{tabular}{|l|l|l|}
\hline Types of extract & Results of sample 1 & Results of sample 2 \\
\hline Water & $(48.53 \pm 0.27) \mathrm{mg} \mathrm{GAE} /$ gram of extract & $(65.29 \pm 1.09) \mathrm{mg}$ GAE/gram of extract \\
\hline Alcohol & $(52.08+2.07) \mathrm{mg} \mathrm{GAE} /$ gram of extract & $(10.11 \pm 0.06) \mathrm{mg}$ GAE/gram of extract \\
\hline
\end{tabular}

TLC (Thin - Layer Chromatography)

Table 6: TLC profile

\begin{tabular}{|c|c|c|c|c|c|}
\hline Solvent system & Wavelength & $\begin{array}{l}\text { No. of spots } \\
\text { sample } 1\end{array}$ & $\begin{array}{l}R_{f} \text { Value obtained } \\
\text { sample } 1\end{array}$ & $\begin{array}{l}R_{f} \text { Value obtained } \\
\text { sample } 2\end{array}$ & $\begin{array}{l}\text { No. of spots } \\
\text { sample } 2\end{array}$ \\
\hline \multirow{2}{*}{$\begin{array}{l}\text { Toluene: } \\
\text { acetate } \\
(9: 1)\end{array}$} & $\begin{array}{l}\text { Short wave } \\
254 \mathrm{~nm}\end{array}$ & 5 & $\begin{array}{l}0.06,0.18,0.63,0.75 \\
0.82\end{array}$ & $\begin{array}{l}0.07,0.22,0.64,0.76 \\
0.82,0.97\end{array}$ & 6 \\
\hline & $\begin{array}{l}\text { Long wave } \\
366 \mathrm{~nm}\end{array}$ & 6 & $\begin{array}{l}0.06,0.40,0.52,0.61 \\
0.82,0.97\end{array}$ & $\begin{array}{l}0.08,0.64,0.75,0.83 \\
0.96\end{array}$ & 5 \\
\hline
\end{tabular}

Table 7: Qualitative Analysis of Inorganic Elements

\begin{tabular}{|l|l|l|}
\hline Inorganic elements & Results(sample1) & Results(sample2) \\
\hline Calcium & Absent & Absent \\
\hline Magnesium & Absent & Absent \\
\hline Potassium & Absent & Absent \\
\hline Iron & Present & Present \\
\hline Sulphate & Present & Present \\
\hline Phosphate & Present & Present \\
\hline Chloride & Present & Present \\
\hline Carbonates & Absent & Absent \\
\hline Nitrates & Absent & Absent \\
\hline Sodium & Present & Present \\
\hline
\end{tabular}

\section{DISCUSSION}

Foreign matter is directly related with the presence of impurities, Foreign matter is more in sample 2.

Total Ash value is high in Sample 2. It indicates that the inorganic material is approximately high in Sample 2 as compare to sample 1

W.S.E. is more in sample $1 \&$ A.S.A value is more in sample 2 .

LOD is high in sample 1. Due to high moisture content, sample 1 has lesser shelf life. So, sample 2 can be stored easily for longer time and preparation made by it also has better shelf life.

Phytochemical analysis of aqueous extract of sample 1 and sample 2 shows absence of pentose sugar, hexose sugar, non-reducing sugar, anthraquinone, coumarine glycosides.

Phytochemical analysis of alcoholic extract of sample 1 and sample 2 shows absence of monosaccharides, pentose sugar, hexose sugar, non-reducing sugar, steroid, anthraquinone, coumarine glycosides, saponin glycosides.

Phytochemical analysis of aqueous extract of sample 2 shows presence of cardiac glycosides. Both the samples contain carbohydrates, reducing sugars, proteins, amino acids, flavonoids, alkaloids, tannins in alcoholic as well as aqueous extract.

Flavonoids are more in sample 1 as compared to sample 2. The flavonoids have been reported to have anti- 
viral, anti-allergic, antiplatelet, anti-inflammatory, anti-tumor and antioxidant activities.

Total phenolic compound is more in sample 2. Phenolic compounds are natural antioxidants having an aromatic ring with one or more hydroxyl groups.

TLC of sample 1 of alcoholic extract of the drug on silica gel plate using toluene; ethyl acetate (9:1) shows 5 spots at short wave and 6 spots at long wave. TLC of sample 2 of alcoholic extract of the drug on silica gel plate using toluene: ethyl acetate (9:1) shows 6 spots at short wave and 5 spots at long wave.

\section{CONCLUSION}

This study revealed that Moringa oleifera Lam is a rich source of phytochemicals which acts against many diseases and it is beneficial in maintaining good health. There is very small difference observed in the phytochemicals of Moringa oleifera Lam of both the areas. The present study suggests that the environmental condition, soil condition, temperature, humidity, rainfall has very little effect on the production of active ingredients of Moringa oleifera Lam according to the two different geographical regions. The presence of various phytochemical in Moringa oleifera Lam leaf may justify its popular consumption and usage in Ayurvedic medicine.

\section{REFERENCES}

1. Rahman MM, Sheikh MMI, Sharmin SA, Islam MS, Rahman MA, Rahman MM, et al, antibacterial activity of leaf juice and extracts of Moringa oleifera Lam. against some human pathogenic bacteria.2009;8(2);291-227

2. Kekuda TRP, Mallikarjun N Swathi D, Nyana K V, Mera B Aiyar, Rohini T R, Antibacterial and antifungal efficacy of steam distillate of Moringa oleifera Lam. J. Pharm. sci. and Res.2010;2(1);34-37

3. Aguwa $\mathrm{CN}$, Nwanko SO. Preliminary studies on the root extract of nulea latifolia smith, for antiulcer properties. nig j pharmaceutical sci.1988;4(1):16-23

4. Bandana M, Khanikor HN, Lahon LC, Mohan O, Barua $\mathrm{C}$. analgesic, anti-inflammatory and local anaesthetic activity of Moringa in laboratory animals. pharmaceutical boil.2003;41(4):248-252.
5. Cheenpracha S, Park EJ, Yoshida WY, Barit C, Wall M, Pezzuto JM, Chang LC. Potenial anti-inflammatory phenolic glycosides from the medicinal plant Moringa oleifera fruits. bioorg md chem. 2010; 18(17);65986602.

6. Nandave A, Ojha SK, Joshi S, Kumara S, Arya DS, Moringa oleifera leaf extract prevents isoproterenol induced myocardial damage in rats; evidence for an antioxidant, antiperoxidative, and cardioprotective intervention. j med food ,2009;12(1):46-55

7. Khandelwal KR. Practical Pharmacognosy; Techniques and experiments, Nirali Prakashan; 2008,149-156.

\section{Source of Support: Nil \\ Conflict of Interest: None Declared}

How to cite this URL: Paramjeet Kaur Sethi et al: Evaluation Of Physicochemical And Phytochemical Composition Of Dry Shigru Patra (Moringa Oleifera Lam. Leaf) Of Island (Port Blair) And Mainland (Chhattisgarh). International Ayurvedic Medical Journal \{online\} 2021 \{cited January, 2021\} Available from: http://www.iamj.in/posts/images/upload/2689 2695.pdf 